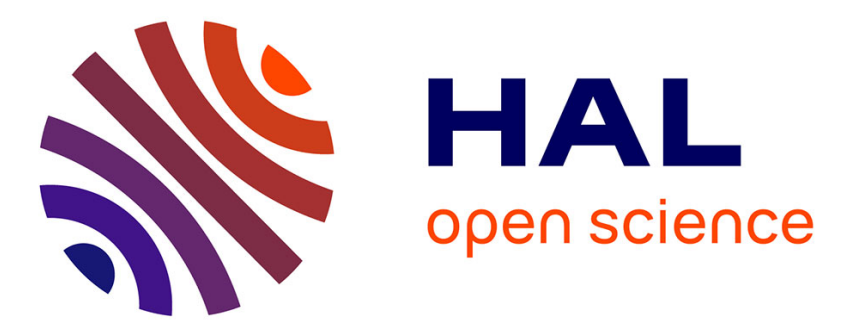

\title{
Studies on chill coma recovery in the ladybird, Harmonia axyridis Ontogenetic profile, effect of repeated cold exposures, and capacity to predict winter survival
} Michal Knapp, Philippe Vernon, D Renault

\section{- To cite this version:}

Michal Knapp, Philippe Vernon, D Renault. Studies on chill coma recovery in the ladybird, Harmonia axyridis Ontogenetic profile, effect of repeated cold exposures, and capacity to predict winter survival. Journal of Thermal Biology, 2018, 74, pp.275-280. 10.1016/j.jtherbio.2018.04.013 . hal-01807843

HAL Id: hal-01807843

https://hal-univ-rennes1.archives-ouvertes.fr/hal-01807843

Submitted on 28 Aug 2018

HAL is a multi-disciplinary open access archive for the deposit and dissemination of scientific research documents, whether they are published or not. The documents may come from teaching and research institutions in France or abroad, or from public or private research centers.
L'archive ouverte pluridisciplinaire HAL, est destinée au dépôt et à la diffusion de documents scientifiques de niveau recherche, publiés ou non, émanant des établissements d'enseignement et de recherche français ou étrangers, des laboratoires publics ou privés. 
1 Studies on chill coma recovery in the ladybird, Harmonia axyridis: ontogenetic profile,

2 effect of repeated cold exposures, and capacity to predict winter survival

3

4 MICHAL KNAPP ${ }^{1 *}$, PHILIPPE VERNON ${ }^{2}$, DAVID RENAULT ${ }^{3,4}$

5

$6{ }^{1}$ Department of Ecology, Faculty of Environmental Sciences, Czech University of Life

7 Sciences Prague, Kamýcká 129, Prague - Suchdol, 165 00, Czech Republic

$8 \quad{ }^{2}$ University of Rennes, CNRS, ECOBIO, UMR 6553, Station Biologique de Paimpont, 35380

9 Paimpont, France

${ }^{3}$ University of Rennes 1, UMR 6553 EcoBio CNRS, 263 Avenue du Gal Leclerc, 35000

11 Rennes Cedex, France

$12{ }^{4}$ Institut Universitaire de France, 1 Rue Descartes, 75231 Paris Cedex 05

$16 *$ Correspondence:

17 Michal Knapp, Department of Ecology, Faculty of Environmental Sciences, Czech University 18 of Life Sciences Prague, Kamýcká 129, Praha - Suchdol, 165 00, Czech Republic. Tel. +420 19224383853 e-mail: knapp@fzp.czu.cz 


\section{Abstract}

The harlequin ladybird, Harmonia axyridis, is one of the most successful invasive insect species worldwide. We investigated whether (i) chill coma recovery time (CCRt) changes during the ontogenetic development of this species, (ii) CCRt varies in response to repeated cold shocks, and (iii) CCRt could be a good predictor of winter survival ability in adults. CCRt decreased during larval development, the lowest CCRt values were observed in teneral adults (one and four days old), and significantly higher values were observed for older adults (16 and 32 days old). Repeated cold shocks (two hours at $-3{ }^{\circ} \mathrm{C}$ ), interrupted by short (30 minutes) warm periods $\left(22^{\circ} \mathrm{C}\right)$ resulted in decreased CCRt after the second cold shock, probably depicting an acclimation response, but then CCRt increased with additional cold shocks, likely revealing the accumulation of chill injuries. The CCRt of pre-overwintering individuals was not correlated with their winter survival. This indicates that CCRt is not a reliable measure of cold tolerance in $H$. axyridis. However, this result could be partially affected by the experimental setup - the use of laboratory-reared individuals who experienced standardized conditions and thus the variability in CCRt of tested animals could be much lower than the variability present in nature. The substantial variation observed over the ontogenetic development of $H$. axyridis poses important methodological implications for future studies, as animals of the same stage/age should be compared with each other. The observed U-shaped response to repeated cold shocks indicates that the expectation of linearity between cold exposure and insect response is an oversimplification of real situations. 
Highlights:

42
- chill coma recovery time (CCRt) varies significantly during ladybird ontogeny

- repeated cold shocks result in a U-shaped CCRt response

- pre-overwintering CCRt was not related to winter survival in this species

- the relevance of CCRt as a measure of cold tolerance needs to be evaluated in other species

\section{Key Words:}

Ageing, chill injury, cold tolerance, invasive species, ontogenetic stage, overwintering 


\section{Introduction}

Because of their ectothermic nature and small body sizes, insects are particularly prone to rapid changes in their body temperature and have had to develop a wealth of behavioural and physiological responses to survive at low temperatures (Teets and Denlinger, 2013). As a result, thermal tolerance is a crucial physiological trait that is significantly related to the distribution of insect species on Earth (Araujo et al., 2013). A range of techniques are available for assessing the cold tolerance of insects; while some of them directly measure mortality (e.g., estimation of survival capacities, measurements of lower lethal limits), other techniques are only proxies of insect tolerance to the deleterious effects of low temperatures (e.g., supercooling point, chill coma onset and recovery; see Terblanche et al., 2011 and Sinclair et al., 2015 for a review).

Chill coma onset and recovery have been described as reliable metrics of thermal plasticity and tolerance in insects (Sinclair et al., 2015). Chill coma is initiated when neuromuscular function is disrupted as a result of the organism's inability to maintain proper ion balance due to depolarization of the resting membrane potential (MacMillan and Sinclair, 2011; Overgaard and MacMillan, 2017). Entering into chill coma has substantial ecological consequences for an individual, as immobile insects are not able to acquire food or escape from predators. While the measurement of the onset of chill coma can be challenging in immature insects, the recovery from chill coma, i.e., the ability of a specimen to exhibit a predetermined behaviour, can be easily measured in both juveniles and adults (see Sinclair et al., 2015 for a discussion of this point).

Chill coma recovery time (CCRt) is expected to differ greatly among and within insect species and particularly among populations of different geographical origin (Andersen et al., 2015; Bowler and Terblanche, 2008; Chown, 2001). Within-population CCRt variations are 
also frequently observed, as developmental plasticity (i.e., the environmental conditions experienced during preimaginal development partly determine adult stress tolerance) or individual acclimation (i.e., exposure to mild stress enhances individual stress tolerance;

Colinet and Hoffmann, 2012; Terblanche and Chown, 2006) can affect this measure.

Moreover, thermal tolerance can substantially vary over the course of an insect's life, but ontogenetic variations in the responses to low temperatures have been poorly examined compared to heat resistance (see Bowler and Terblanche, 2008). The existing studies have focused on preimaginal development or adult ageing (Colinet et al., 2013; David et al., 1998; Halle et al., 2015; Pujol-Lereis et al., 2014), while studies that included measures on both preimaginal and adult stages are commonly focused on a few developmental stages and age classes (e.g., Arias et al., 2011, but see Jensen et al., 2007 on Drosophila melanogaster). Differences between individuals in their cold tolerance are expected to have consequences for their overwintering success (Denlinger and Lee, 2010), but this prediction has only rarely been verified experimentally (e.g., Alford et al., 2014; Kostal et al., 2011).

The majority of studies investigating insect cold hardiness focus on the effects of a single exposure to low temperatures (Marshall and Sinclair, 2012). However, in the field, insects can be exposed to knockdown temperatures on multiple occasions over days, and these repeated exposures could affect insect performance in the following ways: 1) cold hardiness will progressively increase across successive exposures, depicting thermal acclimation; 2) cold hardiness will progressively decrease across successive exposures, revealing an accumulation of chill injuries; 3) cold hardiness will exhibit a complex pattern of a U-shaped cold hardiness response curve as a result of acclimation of the insect during the first sequence of the exposure to the cold conditions, followed by an accumulation phase of chill injuries (Colinet et al., 2016; Marshall and Sinclair, 2012, 2015). 
In this study, we present the results of a pilot study on the thermal biology of the harlequin ladybird, Harmonia axyridis (Pallas, 1773). This species is currently considered one of the most invasive insects worldwide (Brown et al., 2011; Lombaert et al., 2011), with probable specific abilities to colonize cold environments (Barahona-Segovia et al. 2016). $H$. axyridis overwinters as an adult and creates large winter aggregations, frequently in human settlements (Berkvens et al., 2010). Previous studies measured supercooling points and lower lethal temperatures in adult $H$. axyridis originating from European and US invasive populations (Berkvens et al., 2010; Koch et al., 2004) and from Japanese native populations (Watanabe, 2002). To our knowledge, patterns of CCRt variation have not been investigated in this species thus far. We addressed three different questions using a single metric - CCRt: low temperatures in nature (late larval instars can experience colder autumn weather in Central Europe); 2) we investigated the effect of repeated cold exposures on CCRt in adult ladybirds and expected CCRt prolongation because of the accumulation of chill injuries pre-overwintering CCRt for winter survival and expected that individuals achieving lower pre-overwintering CCRt would suffer from lower winter mortality. The ecophysiological meaning of CCRt clearly differs for summer active (questions 1 and 2) and winter diapausing repeated cold shocks. For winter diapausing insects we tested the ecological relevance of 


\section{Materials and Methods}

124

125

126

127

128

129

130

131

132

133

134

135

136

137

138

139

140

141

142

143

144

145

\subsection{Insect collection and rearing}

The parental individuals used in study were collected August 2015 from shrubs and lime trees in the university campus of the Czech University of Life Sciences Prague, Czech Republic (GPS: $50^{\circ} 8^{\prime} \mathrm{N}, 14^{\circ} 21^{\prime} \mathrm{E} ; 300 \mathrm{~m}$ a.s.l.). After transportation to the laboratory, the beetles were sexed, and parental pairs were formed. Each couple was placed in a separate Petri dish $(9 \mathrm{~cm}$ in diameter) containing crumpled filter paper strips, which provided a suitable substrate for egg laying. New egg clutches were placed into Petri dishes and exposed to a standardized laboratory condition (16L:8D photoperiod, $70 \%$ humidity, $26{ }^{\circ} \mathrm{C}$ ). A temperature of $26^{\circ} \mathrm{C}$ is the optimal rearing temperature for H. axyridis (Hodek et al., 2012; Knapp and Nědved, 2013). Newly hatched larvae were fed ad libitum with eggs of Ephestia kuehniella (Zeller, 1879) (Lepidoptera: Pyralidae) and provided with water in cotton wool.

\subsection{Chill coma induction and chill coma recovery time measurements}

For all beetles investigated in the following experiments (sections 2.3., 2.4. and 2.5.), chill coma was induced and chill coma recovery time (CCRt) was measured in a standardized way. Pools of six individuals were placed individually into clean Petri dishes and transferred to -3 ${ }^{\circ} \mathrm{C}$ for two hours. A freezing climatic chamber made on order by AVIKO-PRAHA a.s. company was employed for this purpose. The temperature inside the climatic chamber was monitored with a datalogger Tinytag PLUS2 (Supporting Information file Fig. A.1). After 2 hours at $-3{ }^{\circ} \mathrm{C}$, the Petri dishes were returned to room temperature $\left(22 \pm 1^{\circ} \mathrm{C}\right)$ in an airconditioned laboratory and the beetles were turned onto their dorsum. The duration necessary for observing the first movement of an appendage (most often a leg or a palpus) was measured. As ladybirds can often "play dead” (remain motionless despite being already able 
to move), individuals were stimulated by gentle teasing with an entomological pin every five seconds.

\subsection{Experiment 1: Effects of ontogeny on chill coma recovery time}

Three fecund parental pairs were selected at random, and their offspring were used in the laboratory experiment investigating the ontogenetic development of cold resistance in $H$. axyridis. Egg clutches, hatched larvae and $2^{\text {nd }}$ generation adults were housed under the same rearing conditions as the parental pairs (16L:8D, $26^{\circ} \mathrm{C}, 70 \%$ humidity, food and water ad libitum). Following egg laying, egg clutches were randomly assigned to one of the following eight treatments to assess the effects of ontogenetic stages on CCRt: $1^{\text {st }}$ larval instar, $2^{\text {nd }}$ larval instar, $3^{\text {rd }}$ larval instar, $4^{\text {th }}$ larval instar, newly hatched adult (one-day old), four-day-old adult, 16-day-old adult and 32-day-old adult. CCRt was measured only once for each individual (not repeatedly in the course of the experiment). Ladybirds are long-lived insects, with adult longevity exceeding a year; therefore, senescence is expected to take place far later than at the age of 32 days (Hodek et al., 2012). The first and second instar larvae were reared together (a complete clutch) in one Petri dish. When the larvae moulted to the third instar, they were assigned to new Petri dishes in groups of four to five individuals. The CCRt of six larvae per parental pair was measured per treatment, and the CCRt of five individuals per sex per parental pair per treatment was recorded for adult treatments.

\subsection{Experiment 2: Effects of repeated cold shock on the chill coma recovery time of adults}

Twelve males and twelve females aged 14 to 20 days obtained from the same parental pairs as those individuals from the previous experiment were reared at a constant $26{ }^{\circ} \mathrm{C}$, photoperiod 
16L:8D, $70 \%$ humidity and with food and water ad libitum. One day before the CCRt measurements, the beetles were individually transferred to Petri dishes and were provided with water only (this short food deprivation period was used to reduce the possible confusing effects of variable stomach contents across repeated measurements). Repeated exposures to knockdown temperatures were achieved as follows: each ladybird was transferred to $-3.0{ }^{\circ} \mathrm{C}$ for two hours, then returned to room temperature $\left(22 \pm 1{ }^{\circ} \mathrm{C}\right)$ for 30 minutes before being transferred again to $-3.0^{\circ} \mathrm{C}$. This cyclic procedure was repeated four times (i.e., four exposures of two hours at $-3.0^{\circ} \mathrm{C}$ ), and the CCRt was repeatedly measured for each individual after each exposure to the knockdown temperature (four CCRt measurements for each individual).

\subsection{Experiment 3: Chill coma recovery time and winter survival of adults}

Five males and five females per parental pair were selected at random from 10 parental pairs (i.e., 100 ladybirds in total). Ladybird offspring were reared at $26^{\circ} \mathrm{C}$ (photoperiod 16L:8D, 70 \% humidity) and supplied with food (Ephestia kuehniella eggs) and water ad libitum. On October $7^{\text {th }}$, when the ladybirds were 15-25-day-old adults, the beetles were transferred to an $18{ }^{\circ} \mathrm{C}$ and 12L:12D photoperiod regime to initiate winter diapause. The insects were maintained individually in Petri dishes and supplied with water but without food (as they naturally stop feeding during winter diapause). On October $14^{\text {th }}$, the CCRt was measured (as described above) for each individual. One day later, the thermal regime was changed to fluctuating temperatures and a short photoperiod $\left[8 \mathrm{~L}\left(12^{\circ} \mathrm{C}\right): 16 \mathrm{D}\left(6^{\circ} \mathrm{C}\right)\right]$ to mimic outdoor conditions in late autumn. Six days later, the overwintering phase started and the beetles, still maintained in the climatic chamber, were exposed to the mean temperature regime experienced in outdoor shelters in Prague (data were computed as the long-term mean 
temperature $1 \mathrm{~cm}$ below the soil surface; hourly means from the meteorological station situated in the Crop Research Institute, Praha-Ruzyně were used). The beetles were maintained in clear Petri dishes containing a small watered piece of cotton wool to limit desiccation and placed into the climatic chamber set to the overwintering regime. The climatic chamber was adjusted each hour with a new temperature value (the temperatures applied are attached as Supporting Information file Table A.1). The mean temperature during the overwintering phase was $0.7^{\circ} \mathrm{C}$, and the minimum temperature reached was $-4.1^{\circ} \mathrm{C}$.

In the course of the overwintering experiment, the beetles were checked at monthly intervals (November $16^{\text {th }}$, December $15^{\text {th }}$, January $14^{\text {th }}$, February $17^{\text {th }}$ and March $17^{\text {th, }} 2016-$ when the overwintering experiment was terminated). During all inspections, the Petri dishes with beetles were moved to outdoor conditions to minimize unwanted warming of the experimental beetles, the survival of each individual was recorded, and a new piece of watered cotton wool was inserted into each Petri dish (the old one was removed). Live diapausing ladybirds are commonly tightly attached to the substrate, whereas dead individuals have dropped off and are lying freely on their dorsum. Petri dishes with dead individuals were not removed from the experiment as there was a little risk of false death records (an animal seeming to be dead but is still alive); however, no false records were revealed.

\subsection{Statistical analyses}

To analyse ontogenetic changes in the CCRt, a linear mixed-effects model (LME) was run using the "Ime” function implemented in the "nlme” package (Pinheiro et al., 2013) for R (R Development Core Team, 2016). Parental pair identity was used as a random effect in our analysis. Ontogenetic stage was used as a fixed effect in our model. Tukey’s HSD test was employed to test for significant differences between particular ontogenetic stages using the 
"glht" function as implemented in the "multcomp" package (Hothorn et al., 2008). Raw data serving as inputs for the abovementioned analysis are available in the Supporting Information file (Table A.2).

To analyse the effects of repeated cold exposures on the CCRt, a linear mixed-effects model (LME) was conducted using the "Ime" function implemented in the "nlme" package (Pinheiro et al., 2013) for R (R Development Core Team, 2016). Beetle identity was used as a random effect in our analysis. The order of cold exposure (from 1 to 4; a continuous variable) was used as a fixed effect in our model, while a quadratic term was also included in the model for the case where the response would not be purely linear. The significance of the independent variables (order, order ${ }^{2}$ ) was tested using F-tests (“anova.lme” function). To test for the real necessity of both terms (order, order ${ }^{2}$ ) in the final model, the most parsimonious model based on AIC-values was also selected (Akaike, 1974). Raw data are available in the Supporting Information file (Table A.3).

To analyse the effects of CCRt on H. axyridis survival during winter, the Cox proportional-hazards model (Cox-PH) was run using the "coxph" function implemented in the “survival” package (Therneau, 2015) for R (R Development Core Team, 2016). Winter survival in months (one to five months) was used as the response variable, and CCRt was used as an independent variable in the model. Beetles that survived until the end of the experiment (March) were excluded in the model, as their future longevity was unknown. Raw data serving as inputs for the above analysis are available in the Supporting Information file (Table A.4).

The effects of sex on the CCRt were analysed in the preliminary analyses performed for all experiments. As there were no significant effects of sex in any model, this term was not included in the final models. 


\section{Results}

244 There were significant changes in chill coma recovery time (CCRt) during the ontogenetic 245 development of the harlequin ladybird, Harmonia axyridis (LME: $\mathrm{F}=19.92, \mathrm{P}<0.001)$. The 246 CCRt decreased by ca. $22 \%$ in the course of early larval development from the $1^{\text {st }}$ to $2^{\text {nd }}$ 247 larval instars and reached the lowest value in teneral adults (between one and four days old adults). The CCRt of older adults (16 or 32 days old adults) was increased and did not differ

249 from the CCRt of the $2^{\text {nd }}, 3^{\text {rd }}$ and $4^{\text {th }}$ larval instars (Fig. 1).

Repeated two-hour exposures to sub-zero temperatures interrupted by 30 -minute recovery periods at $22{ }^{\circ} \mathrm{C}$ resulted in increasing the CCRt from the second cold exposure onwards in H. axyridis. However, the CCRt decreased from the first to the second cold exposure; thus, alongside the significant linear term (LME: $\mathrm{F}=23.92, \mathrm{P}<0.001)$, there was also a significant quadratic term in the final statistical model $(\mathrm{F}=11.24, \mathrm{P}=0.001)$. The most parsimonious model included both terms (order and order²) according to the AIC (Table 1), demonstrating that a U-shaped response to repeated cold exposures was measured in $H$. axyridis (Fig. 2).

No significant relationship was observed between the CCRt of the pre-overwintering individuals and their ability to survive during the winter (Cox-PH: $\mathrm{z}=-1.50, \mathrm{P}=0.13$ ). The observed trend was even opposite that of the hypothesized one: the four individuals who had the lowest CCRt died during the first months of the winter, whereas the three individuals with the highest CCRt survived until the last month of the winter (two of them even survived the whole winter; Fig. 3). 
In this work, we used CCRt to examine different aspects of ladybird thermal physiology: we

267

1) investigated the physiological changes during ontogeny, 2) examined the physiological responses of summer active ladybirds to repeated cold shocks, and 3) investigated the relevancy of the CCRt as a proxy for winter cold hardiness. Significant variations of the CCRt were measured across the ontogeny of Harmonia axyridis, with the lowest CCRt values observed in teneral adults. Repeated cold shocks altered the CCRt of $H$. axyridis, and a Ushaped response was measured, with reduced CCRt during the first phase, followed by a CCRt increase when the number of cold shocks was increased. Finally, we found no relationship between the CCRt of pre-overwintering individuals and their subsequent ability to survive during the winter months.

Changes in the degree of heat tolerance during ontogeny are widespread in insects, but adjustments to cold resistance during ontogeny have been less examined (e.g., Bowler and Terblanche, 2008; Klockmann et al., 2017; Knapp and Nědved, 2013; Zhao et al., 2017). Relevant experimental data that reported ontogenic variations of insect cold resistance exist mostly for insect model species (e.g., Arias et al., 2011; Colinet et al., 2013; Jensen et al., 2007; Pujol-Lereis et al., 2014; for the review of older studies see Bowler and Terblanche, 2008). In univoltine holometabolous species, differences in coping with cold exposures among stages could reflect adaptive responses, as the development stages can experience different thermal conditions, with the overwintering stage being most often the most coldresistant one (Denlinger and Lee, 2010). Nevertheless, adjustments of insect cold hardiness are not only dictated by environmental temperatures, as differences have also been reported during the ontogeny of multivoltine species over the course of the growth season (e.g., Jensen et al., 2007). One of possible explanations is that levels of heat-shock proteins (HSPs), which are partially responsible for the actual cold resistance and are also involved in various stress 
responses unrelated to cold challenge, vary substantially in the course of insect ontogeny (Colinet et al., 2013), including in the harlequin ladybird (Wang et al., 2017).

There is no unified ontogenetic profile of cold resistance observed for a wide range of insect species. In our study, CCRt was significantly higher in the $1^{\text {st }}$ larval instar compared with later larval instars. Interestingly, Jensen et al. (2007) observed a distinct pattern of lower lethal temperature causing $50 \%$ mortality $\left(\mathrm{LT}_{50}\right)$ in Drosophila melanogaster, which slightly increased from the $2^{\text {nd }}$ to the $3^{\text {rd }}$ larval instar. We measured the lowest CCRt value in teneral ladybird adults, which is consistent with the finding of Jensen et al., (2007) for $D$. melanogaster, but opposite the pattern reported for Tenebrio molitor (Arias et al., 2011). Differences in the changes of ontogenetic patterns of CCRts across species may result from the distinct life histories of the studied species, particularly in terms of overwintering strategies. Importantly, the contrasting cold resistance patterns among studies can also be caused by the various proxies that are employed, as these measures are not necessarily correlated (Andersen et al., 2015).

The higher cold resistance of teneral adults (few hours/days old) of D. melanogaster reported by Colinet et al. (2013) was also found in our study for $H$. axyridis. The cold resistance of adult ladybirds subsequently decreased with increasing age, a pattern also observed for D. melanogaster and Ceratitis capitata (David et al., 1998; Pujol-Lereis et al., 2014). Decreased cold hardiness with age in adult insects was thought to be related to senescence-associated processes (Bowler and Terblanche, 2008; Halle et al., 2015). However, this hypothesis is unlikely for our 32-day-old H. axyridis whose longevity can easily reach one year; senescence is thus expected to take place later in their lives (Hodek et al., 2012; note also that the CCRt slightly decreased from the age of 16 days to 32 days in our study). Moreover, increasing cold resistance in the course of senescence was observed for the subAntarctic fly Anatalanta aptera (Lalouette et al., 2010). Altogether, our results have important 
methodological implications for future studies on insect cold hardiness, as the exact age of experimental animals should be precisely stated, and animals of the same stage/age should be compared with each other in studies investigating issues other than the effects of ontogeny.

Low temperatures cause chill injuries to chill-susceptible insects, and the extent of the injuries depends on the severity of the treatment, i.e., the severity of the temperatures experienced and the duration of exposure (Marshall and Sinclair, 2015; Overgaard and MacMillan, 2017). Despite the fact that thermal fluctuations are ubiquitous in nature, the majority of ecophysiological studies are focused on exposures of insects to a single period at low temperature (Marshall and Sinclair, 2012; see the literature focusing on fluctuating thermal regimes and repeated cold exposures, e.g., Colinet et al., 2016; Marshall and Sinclair, 2015). In this study, we observed the changes in CCRt values in $H$. axyridis subjected to repeated cold shocks and found that values decreased in the first stage followed by a continuous increase from the second exposure onwards. The observed U-shaped response curve depicted the interplay between acclimation (rapid cold-hardening response; Lee et al., 1987) elicited by the first cold exposure and the accumulation of chill injuries (e.g., the creation of reactive oxygen species; Lalouette et al., 2011) inflicted by each successive cold shock. The short warm periods may not have been sufficient for restoring the aerobic metabolism of the insects and completely repairing the physiological injuries caused by exposures to low temperatures (Colinet et al., 2016). A few hours may have been needed for a complete recovery of the injuries accumulated by cold-shocked ladybirds. For example, five cold exposures separated by recovery periods of 24 hours lowered CCRt values in the red flour beetle (Scharf et al., 2018). The physiological responses of insects to repeated cold stress are still not known in detail and it is possible that rapid switching between stress and injury repair states itself poses some physiological costs (Marshall and Sinclair, 2015). 
overwintering specimens of $H$. axyridis and their subsequent overwintering success. This

finding is surprising as between- and within-species variations in CCRt commonly exist in

correlates to their distribution ranges (winter conditions experienced; Andersen et al., 2015;

Chown, 2001), and overwintering individuals often have a significantly lower CCRt

compared with their relatives sampled during the breeding season (Chown, 2001). Our data

even showed slight support for the opposite pattern, i.e., individuals with the lowest CCRt

died in early winter while those with the highest CCRt survived. A possible explanation is a

higher metabolic rate in animals with lower CCRt (Williams et al., 2016). Animals with

higher energy demands can die during overwintering due to the depletion of their energy reserves.

A possible shortcoming of our study is that overwintering success was investigated for laboratory-reared insects that experienced standardized environmental conditions. Moreover, their genetic variability may have been limited (all were offspring of 10 parental pairs). This experimental setting may have reduced the differences in CCRt values among individuals compared with the variation existing for individuals in the field. As laboratory rearing could affect ladybird overwintering performance (Berkvens et al., 2010), we encourage a repetition of this experiment using pre-overwintering individuals collected directly in the field. As winter survival in insects is a result of complex interactions between individual physiological traits and environmental conditions, future research investigating the effects of individual cold resistance (represented by various measures/proxies) on winter survival under various overwintering conditions for various insect species is needed to disentangle the effects of individual traits on winter survival in insects. If additional studies confirm that CCRt is not the most reliable predictor of insect overwintering success, chill coma temperatures or lower 
lethal temperatures, both good predictors of the latitudinal distribution of Drosophila species, (Andersen et al., 2015) might be used as better indicators of overwintering success.

\section{Conclusions}

This study provides the first measurements of chill coma recovery time (CCRt) in the invasive harlequin ladybird, Harmonia axyridis. We showed substantial changes in CCRt in the course of the ontogenetic development of $H$. axyridis. The significant ontogenetic signal in $H$. axyridis cold hardiness poses important methodological implications for future studies, as animals of the same stage/age should be compared with each other. We also showed that repeated exposures to cold shocks interrupted by short warm periods caused a U-shaped cold resistance response. Individual CCRt was a bad predictor of $H$. axyridis overwintering success. Together with the limited evidence in the existing literature, our results indicated that CCRt is not a reliable measure of insect overwinter success. Future studies investigating the relationship between prewintering CCRt and following winter survival for various insect species are needed to extend the generality of this pattern.

\section{Acknowledgements}

We are grateful to Michal Řeřicha and Radek Svoboda for their help with the laboratory rearing of ladybirds and realization of the overwintering experiment and to Oldřich Nedvěd for sharing his knowledge of $H$. axyridis thermal biology. We are also grateful to six reviewers who significantly improved the language quality of the text and provided us with insightful suggestions on a previous version of the manuscript. 
387 Funding: This study was supported by grant no. 42900/1312/3166 awarded by the Internal Grant Agency of the Czech University of Life Sciences Prague.

Appendices:

391 The following additional supporting information may be found in the online version of this 392 article.

393 Table A.1 - Temperature profile experienced by ladybirds during overwintering in 394 computer-instructed freezing climatic chambers.

395 Table A.2 - Raw data analysed in experiment 1 (Ontogeny).

396 Table A.3 - Raw data analysed in experiment 2 (Repeated cold shock).

397 Table A.4 - Raw data analysed in experiment 3 (Winter survival).

398 Fig. A.1 - Temperature record from a datalogger placed between the Petri dishes with 399 ladybirds during chill coma induction. 
401 Table 1. Effect of repeated cold shocks on chill coma recovery time- model selection.

402 The most parsimonious linear mixed effect model (the first line) was selected on the basis of 403 the Akaike information criterion (AIC). The term "order” indicates the linear effects of the 404 cold shock order on chill coma recovery time; the term "order" ${ }^{2}$ " indicates the quadratic (non405 linear) effect of the cold shock order on the chill coma recovery time. A difference in the 406 AIC-value $(\Delta$ AIC) $>2$ indicates a significant difference between models, i.e., the model with 407 lower AIC-value is significantly more parsimonious.

\section{Model structure}

Independent variable Random effect AIC-value $\triangle$ AIC

$\sim$ order + order $^{2} \quad$ individual beetle $826.303 \quad 0.000$

$\sim$ order $^{2}$

individual beetle $\quad 836.124 \quad 9.821$

individual beetle $\quad 837.654 \quad 11.352$


Fig. 1. Effect of ontogenetic stage on cold resistance of Harmonia axyridis. The mean chill

411 coma recovery time (CCRt) values + SEM based on 18 larvae measured per instar (grey bars)

412 and 30 adults (15 males and 15 females) measured per adult age class (black bars) are shown.

413 Significant differences (Tukey post hoc test: $\mathrm{P}<0.05$ ) in CCRt among particular ontogenetic

414 stages are indicated by unshared letters above the bars.

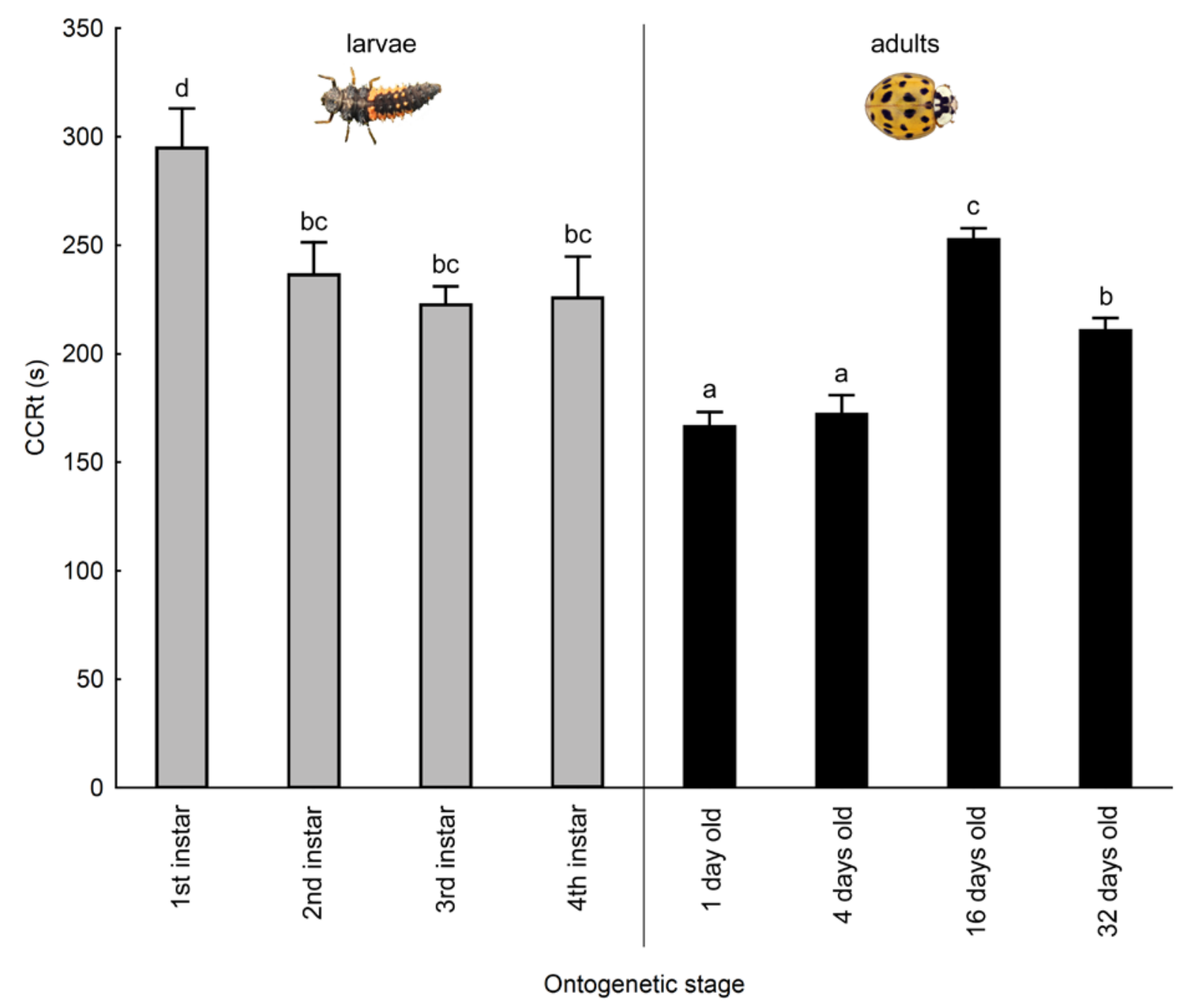


417 Fig. 2. Effect of repeated cold shocks on chill coma recovery time in adult Harmonia axyridis. Mean chill coma recovery time (CCRt) values + SEM are shown. Each ladybird (24

419 in total) was exposed to four successive cold shocks (two hours at $-3{ }^{\circ} \mathrm{C}$ ) interrupted by short 420 warm periods (30 minutes at $22{ }^{\circ} \mathrm{C}$ ). The CCRt was measured for each individual after each 421 cold shock.

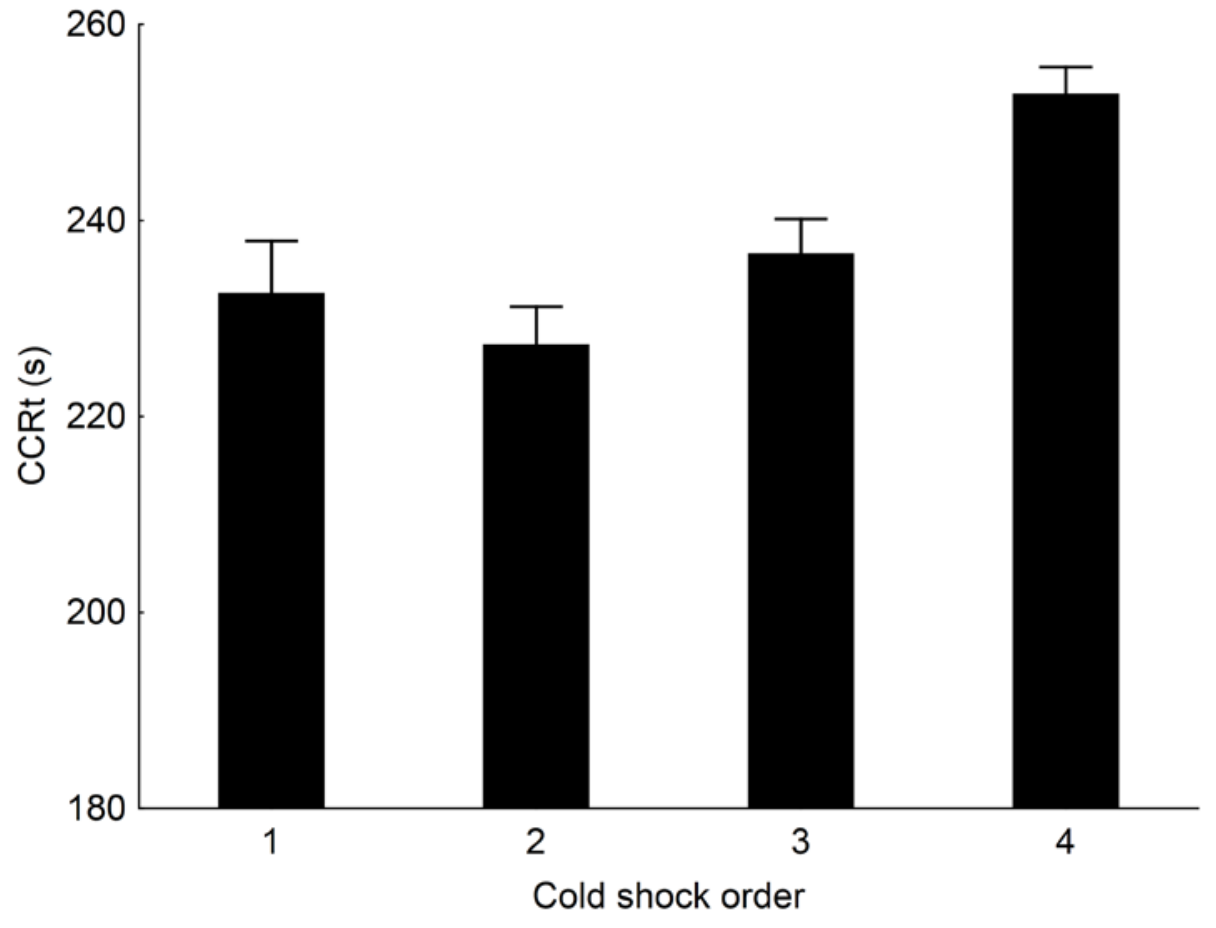


425 subsequent winter survival. Dates on the vertical axis indicate control dates, i.e., the dates 426 on which a given beetle was seen alive for the last time. Survival until March $17^{\text {th }}$ indicates

427 successfully completed overwintering. Short vertical lines indicate the mean pre-

428 overwintering chill coma recovery time (CCRt) achieved by individuals who were seen alive 429 for the last time during a given control.

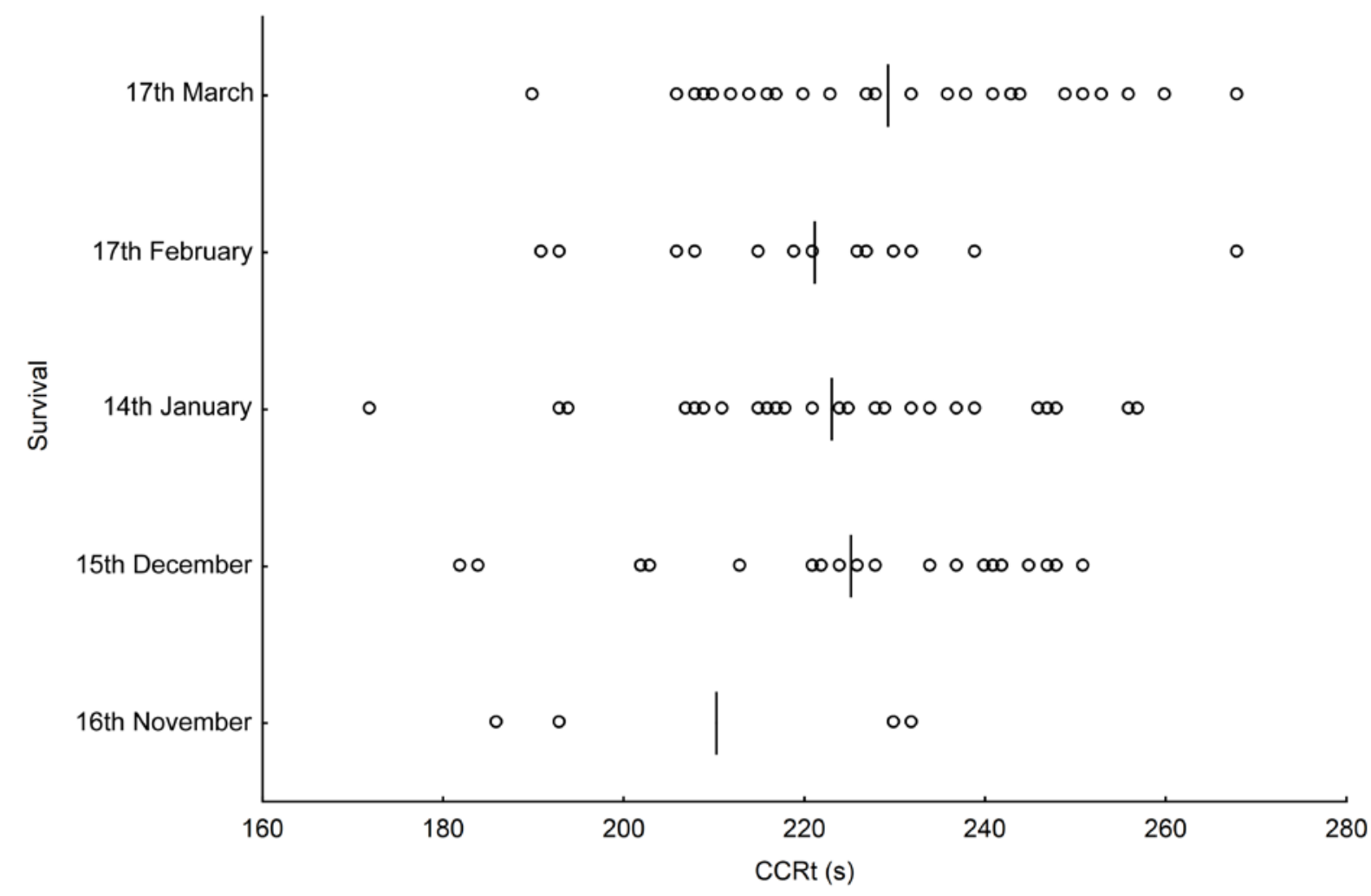

430 
433

434

435

436

437

438

439

440

441

442

443

444

445

446

447

448

449

450

451

452

453

454

455

456

457

458

459

460

461

462

463

464

465

466

467

468

469

470

471

472

473

474

475

476

477

478

479

480

481

Akaike, H., 1974. New look at statistical-model identification. IEEE Trans. Autom. Control. AC19, 716723.

Alford, L., Andrade, T.O., Georges, R., Burel, F., van Baaren, J., 2014. Could Behaviour and Not Physiological Thermal Tolerance Determine Winter Survival of Aphids in Cereal Fields? Plos One 9, e114982.

Andersen, J.L., Manenti, T., Sorensen, J.G., MacMillan, H.A., Loeschcke, V., Overgaard, J., 2015. How to assess Drosophila cold tolerance: chill coma temperature and lower lethal temperature are the best predictors of cold distribution limits. Funct. Ecol. 29, 55-65.

Araujo, M.B., Ferri-Yanez, F., Bozinovic, F., Marquet, P.A., Valladares, F., Chown, S.L., 2013. Heat freezes niche evolution. Ecol. Lett. 16, 1206-1219.

Arias, M.B., Poupin, M.J., Lardies, M.A., 2011. Plasticity of life-cycle, physiological thermal traits and Hsp70 gene expression in an insect along the ontogeny: Effect of temperature variability. J. Therm. Biol. 36, 355-362.

Barahona-Segovia, R.M., Grez, A.A., Bozinovic, F., 2016. Testing the hypothesis of greater eurythermality in invasive than in native ladybird species: from physiological performance to lifehistory strategies. Ecol. Entomol. 41, 182-191.

Berkvens, N., Bale, J.S., Berkvens, D., Tirry, L., De Clercq, P., 2010. Cold tolerance of the harlequin ladybird Harmonia axyridis in Europe. J. Insect Physiol. 56, 438-444.

Bowler, K., Terblanche, J.S., 2008. Insect thermal tolerance: what is the role of ontogeny, ageing and senescence? Biol. Rev. 83, 339-355.

Brown, P.M.J., Thomas, C.E., Lombaert, E., Jeffries, D.L., Estoup, A., Handley, L.-J.L., 2011. The global spread of Harmonia axyridis (Coleoptera: Coccinellidae): distribution, dispersal and routes of invasion. Biocontrol 56, 623-641.

Chown, S.L., 2001. Physiological variation in insects: hierarchical levels and implications. J. Insect Physiol. 47, 649-660.

Colinet, H., Hoffmann, A.A., 2012. Comparing phenotypic effects and molecular correlates of developmental, gradual and rapid cold acclimation responses in Drosophila melanogaster. Funct. Ecol. 26, 84-93.

Colinet, H., Renault, D., Javal, M., Berkova, P., Simek, P., Kostal, V., 2016. Uncovering the benefits of fluctuating thermal regimes on cold tolerance of Drosophila flies by combined metabolomic and lipidomic approach. BBA - Mol. Cell Biol. L. 1861, 1736-1745.

Colinet, H., Siaussat, D., Bozzolan, F., Bowler, K., 2013. Rapid decline of cold tolerance at young age is associated with expression of stress genes in Drosophila melanogaster. J. Exp. Biol. 216, 253-259.

David, R.J., Gibert, P., Pla, E., Petavy, G., Karan, D., Moreteau, B., 1998. Cold stress tolerance in Drosophila: Analysis of chill coma recovery in D. melanogaster. J. Therm. Biol. 23, 291-299.

Denlinger, D.L., Lee, R.E., 2010. Low temperature biology of insects. Cambridge University Press, Cambridge, UK.

Halle, S., Nowizki, A., Scharf, I., 2015. The consequences of parental age for development, body mass and resistance to stress in the red flour beetle. Biol. J. Linn. Soc. 115, 305-314.

Hodek, I., Honěk, A., van Emden, H.F., 2012. Ecology and Behaviour of the Ladybird Beetles (Coccinellidae). Willey-Blackwell, Chichester, UK.

Hothorn, T., Bretz, F., Westfall, P., 2008. Simultaneous inference in general parametric models. Biomet. J. 50, 346-363.

Jensen, D., Overgaard, J., Sorensen, J.G., 2007. The influence of developmental stage on cold shock resistance and ability to cold-harden in Drosophila melanogaster. J. Insect Physiol. 53, 179-186.

Klockmann, M., Gunter, F., Fischer, K., 2017. Heat resistance throughout ontogeny: body size constrains thermal tolerance. Glob. Change Biol. 23, 686-696.

Knapp, M., Nědved, O., 2013. Gender and Timing during Ontogeny Matter: Effects of a Temporary High Temperature on Survival, Body Size and Colouration in Harmonia axyridis. Plos One 8, e74984. 
Koch, R.L., Carrillo, M.A., Venette, R.C., Cannon, C.A., Hutchison, W.D., 2004. Cold hardiness of the multicolored Asian lady beetle (Coleoptera : Coccinellidae). Environ. Entomol. 33, 815-822.

Kostal, V., Dolezal, P., Rozsypal, J., Moravcova, M., Zahradnickova, H., Simek, P., 2011. Physiological and biochemical analysis of overwintering and cold tolerance in two Central European populations of the spruce bark beetle, Ips typographus. J. Insect Physiol. 57, 1136-1146.

Lalouette, L., Vernon, P., Amat, H., Renault, D., 2010. Ageing and thermal performance in the subAntarctic wingless fly Anatalanta aptera (Diptera: Sphaeroceridae): older is better. Biol. Lett. 6, 346349.

Lalouette, L., Williams, C.M., Hervant, F., Sinclair, B.J., Renault, D., 2011. Metabolic rate and oxidative stress in insects exposed to low temperature thermal fluctuations. Comp. Biochem. Physiol., Part A Mol. Integr. Physiol. 158, 229-234.

Lee, R.E., Chen, C.P., Denlinger, D.L., 1987. A rapid cold-hardening process in insects. Science 238, 1415-1417.

Lombaert, E., Guillemaud, T., Thomas, C.E., Handley, L.J.L., Li, J., Wang, S., Pang, H., Goryacheva, I., Zakharov, I.A., Jousselin, E., Poland, R.L., Migeon, A., van Lenteren, J., De Clercq, P., Berkvens, N., Jones, W., Estoup, A., 2011. Inferring the origin of populations introduced from a genetically structured native range by approximate Bayesian computation: case study of the invasive ladybird Harmonia axyridis. Mol. Ecol. 20, 4654-4670.

MacMillan, H.A., Sinclair, B.J., 2011. Mechanisms underlying insect chill-coma. J. Insect Physiol. 57, 12-20.

MacMillan, H.A., Williams, C.M., Staples, J.F., Sinclair, B.J., 2012. Reestablishment of ion homeostasis during chill-coma recovery in the cricket Gryllus pennsy/vanicus. PNAS 109, 20750-20755.

Marshall, K.E., Sinclair, B.J., 2012. The impacts of repeated cold exposure on insects. J. Exp. Biol. 215, 1607-1613.

Marshall, K.E., Sinclair, B.J., 2015. The relative importance of number, duration and intensity of cold stress events in determining survival and energetics of an overwintering insect. Funct. Ecol. 29, 357366.

Overgaard, J., MacMillan, H.A., 2017. The Integrative Physiology of Insect Chill Tolerance. Ann. Rev. Physiol., 79, 187-208.

Pinheiro, J., Bates, D., DebRoy, S., Sarkar, D., R Development Core Team, 2013. Nlme: linear and nonlinear mixed effects models. R package version 3.1-107.

Pujol-Lereis, L.M., Rabossi, A., Quesada-Allue, L.A., 2014. Analysis of survival, gene expression and behavior following chill-coma in the medfly Ceratitis capitata: Effects of population heterogeneity and age. J. Insect Physiol. 71, 156-163.

R Development Core Team, 2016. R: A language and environment for statistical computing. $R$ Foundation for Statistical Computing, Vienna, Austria. URL http://www.R-project.org.

Scharf I., Wertheimer, K.O., Xin, J.L., Gilad, T., Goldenberg, I., Subach, A., 2018. Context-dependent effects of cold stress on behavioral, physiological, and life-history traits of the red flour beetle. Insect Sci. in press.

Sinclair, B.J., Alvarado, L.E.C., Ferguson, L.V., 2015. An invitation to measure insect cold tolerance: Methods, approaches, and workflow. J. Therm. Biol. 53, 180-197.

Teets, N.M., Denlinger, D.L., 2013. Physiological mechanisms of seasonal and rapid cold-hardening in insects. Physiol. Entomol. 38, 105-116.Terblanche, J.S., Hoffmann, A.A., Mitchell, K.A., Rako, L., le Roux, P.C., Chown, S.L., 2011. Ecologically relevant measures of tolerance to potentially lethal temperatures. J. Exp. Biol. 214, 3713-3725.

Terblanche, J.S., Chown, S.L., 2006. The relative contributions of developmental plasticity and adult acclimation to physiological variation in the tsetse fly, Glossina pallidipes (Diptera, Glossinidae). J. Exp. Biol. 209, 1064-1073.

Therneau, T., 2015. A Package for Survival Analysis in S. version 2.38. https://CRAN.Rproject.org/package=survival. 
532 Wang, H.J., Shi, Z.K., Shen, Q.D., Xu, C.D., Wang, B., Meng, Z.J., Wang, S.G., Tang, B., Wang, S., 2017. 533 Molecular Cloning and Induced Expression of Six Small Heat Shock Proteins Mediating Cold-Hardiness 534 in Harmonia axyridis (Coleoptera: Coccinellidae). Front. Physiol. 8: 60.

535 Watanabe, M., 2002. Cold tolerance and myo-inositol accumulation in overwintering adults of a lady 536 beetle, Harmonia axyridis (Coleoptera : Coccinellidae). Eur. J. Entomol. 99, 5-9.

537 Williams, C.M., Szejner-Sigal,A., Morgan, T.J., Edison, A.S., Allison, D.B., Hahn, D.A., 2016. Adaptation 538 to low temperature exposure increases metabolic rates independently of growth rates. Integr. Comp. 539 Biol. 56, 62-72.

540 Zhao, F., Hoffmann, A.A., Xing, K., Ma, C.S., 2017. Life stages of an aphid living under similar thermal 541 conditions differ in thermal performance. J. Insect Physiol. 99, 1-7. 